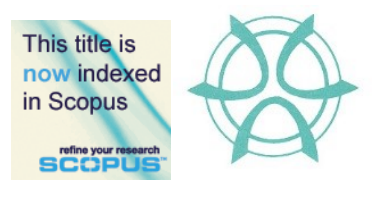

PLANNING MALAYSIA:

Journal of the Malaysian Institute of Planners

VOLUME 19 ISSUE 3 (2021), Page 326 - 337

\title{
EXPRESS CONDITION OF LAND, USAGE OF PROPERTY, AND LICENSING OF SHORT-TERM ACCOMMODATIONS
}

\author{
Nuraisyah Chua Abdullah ${ }^{1}$, Azni Mohd Dian ${ }^{2}$, \\ Ramzyzan Ramly ${ }^{3}$ \\ 1,2 Faculty of Law \\ UNIVERSITI TEKNOLOGI MARA \\ ${ }^{3}$ School of Mechanical Engineering, College of Engineering \\ UNIVERSITI TEKNOLOGI MARA
}

\begin{abstract}
Contrary to many short-term accommodation operators (STAs), short-term accommodations in Malaysia are subjected to laws relating to land and town planning. In the light of the ignorance of the STA operators about the legal aspects of STAs and complaints received by both the industry players (registered hoteliers) and the general community at large, this paper addresses the elements of an express condition of the land, usage of the property and licensing of the STAs in Malaysia. This paper uses the library-based approach, where the analysis of relevant legislation, newspaper report, decided cases, and journal articles are made. A comparative study with selected states in the U.S.A is made concerning the legal status of the short-term rentals.
\end{abstract}

Keyword: short-term accommodation, governance, land office, local authorities

\footnotetext{
${ }^{1}$ Corresponding Author: nuraisyahc@yahoo.com
} 
PLANNING MALAYSIA

Journal of the Malaysia Institute of Planners (2021)

\section{INTRODUCTION}

Nowadays, many people are renting out entire houses or apartments to short-term visitors and operate as short-term accommodation (from now on referred to as STA) operators without having proper registration of the business. In worst-case scenarios, entrepreneurs lease many apartments and operate them as STAs (which is sometimes referred to as 'homestays' or 'guesthouses' with scant regard for permanent residents living there. Housing developers could switch to more oneroom studio apartments with cheaper private residence utility rates, as commercial charges apply to service apartments or small office home offices. Buyers of such studio apartments are least likely to object if many units are used for so-called homestays or guesthouses. Commercialized STAs have become a trend and growing at breakneck speed in cities without specific regulations, as perceived by many people. In the light of the ignorance of the STA operators about the legal aspects of STAs and complaints received by both the industry players (registered hoteliers) and the general community at large, by using a library-based approach, where the analysis of relevant legislation, newspaper report, decided cases and journal articles is made, this paper addresses the aspects of the condition of the land, usage of the property and licensing of the STAs in Malaysia, given the challenges endured in the governance of urban complexities in the ethos of global intensities (Faizul Abdullah \& Fatimah Yusof, 2016). A comparative study with selected states in the U.S.A is made concerning the legal status of the short-term rentals. The selected states in the U.S.A. are made since the U.S.A. has a diverse framework in addressing the legal issues of STAs and because of some features of similarity in the concept of federalism practiced in the U.S.A and Malaysia.

The Federal Constitution of Malaysia 1957, the country's supreme law, prescribes a two-tier governmental structure that is the Federal and State Government. Federal intervention on the grounds of achieving uniformity of land law and policy in Malaysia was initiated by the introduction of the National Land Code 1965 (herein after referred to as NLC). Landed properties in Malaysia are subjected to the governance of town planning in each district. After independence, the town and country planning system were re-organized in line with the new government system whereby the responsibilities between Federal and State Governments are stipulated in the Federal Constitution. Under Article 74(1) of the Federal Constitution, read together with the Concurrent List in the Ninth Schedule, matters related to town planning (and local government) are the concurrent responsibility of both governments. This is, however, complicated by the fact that land is under the constitutional jurisdiction of state governments.

One of the planning administrative bodies that play a significant role in the planning system under the Town and Country Planning Act 1976 (Act 172) is the Local Planning Authority, as provided under Section 5(1) of Act 172. The powers and obligations of Act 172 in the town and country planning domain are 
Nuraisyah Chua Abdullah, Azni Mohd Dian, Ramzyzan Ramly

Express Condition of Land, Usage of Property, And Licensing of Short-Term Accommodations

defined in Section 12(1) of Act 172, and this includes the responsibility to immediately initiate the preparation of structure plans for the consideration of the State Planning Committee even before the State Authority gives assent to a draft structure plan that has been prepared (Izuandi Yin \& Jamalunlaili Abdullah, 2020). As regulated under Act 172, powers of Act 172 in matters concerning land development are constrained as they cannot approve developments that are contrary to the approved development plans (i.e., structure and local plans). Hence, statutory development plans play an essential role in the development control system (Faizah Ahmad, 2001-2011). All Local Planning Authorities are entirely within the purview of the State Government, and the Federal Government has no direct power to intervene in their affairs.

Administratively, town and country planning in Malaysia is carried out at three levels; at the federal level, the Ministry of Housing and Local Government via Federal Town and Country Planning Department, which is responsible for formulating and administering all national policies relating to town and country planning. At the state level, the State Department of Town and Country Planning through the State Planning Committee acts as an advisory body to the state government. While at the ground level, local authorities have the task to carry out town and country planning functions as prescribed in the local plan (Abdul Aziz, Zakaria, \& Hamzah, 2011) (Alden \& Awang, 1985).

Beyond the legal structure prescribed in Act 172, planning administration encompasses three levels of town planning departments which provide the technical and administrative support for the respective levels of government. The Federal Town and Country Planning Department (FTCPD) under the Ministry of Housing and Local Government operates within Peninsular Malaysia, while Sabah and Sarawak each have their equivalent State-level ministries.

\section{GOVERNANCE OF LAND OFFICE IN STA OPERATION}

Can an owner of STA who operates STA use land other than what is stated in the condition? Application for land use conversion can be made under the NLC. Section 52(1)(a) of the NLC provides that all alienated lands are divided into three (3) categories of land use, i.e., "Agriculture," "Building," and "Industry." Section 52 (1) (b) of the NLC states that the State Authority may specify the conditions that attached to the alienated land to include (a) the express conditions; Section 121 for Agriculture land; and Section 122 for Building and Industry (b) the implied conditions: Section 115 for Agriculture; Section 116 for Building; and Section 117 for Industry. Section 104 of the NCL provides conditions to be complied with not only by the proprietor but also every person/body claiming an interest in the land. e.g., chargee (bank), tenant and lessee. Failure to do so will lead to a breach of the condition under Section 125 of the NLC, and the State 
Authority can forfeit the land under Section 127 as illustrated in the case of Lam Eng Rubber Factory (M) Sdn Bhd v State Director, Kedah (1994) 1 CLJ 179.

In 2014, the Penang state government decided to regulate the conversion of residential premises by allowing limited commercial activities. With amendments to Petaling Jaya Local Plan 1 and 2, 19 areas in the city were rezoned from residential to limited commercial status (Brenda Ch'ng, 2016).

Under Section 124 of the NLC, variation of a condition of the land use can be made. Section 124 (1) State Authority is empowered to vary conditions on the application of proprietor of any category of land use: Section 124(5) Approval made by the State Authority may be conditional upon all or any of the following matters-

(a) the payment of a further premium;

(aa) the payment of any other charges as may be prescribed;

(b) the reservation of a new rent;

(c) compliance with such other requirements as the State Authority may think fit.

In the case, Pengarah Tanah dan Galian, Wilayah Persekutuan $v$ Sri Lempah Enterprise Sdn Bhd [1979] 1 MLJ 135, the state authority imposed a condition to approving conversion that the applicant has to surrender the land in perpetuity and would get back the land for a term of 99 years. The Federal Court held that the State Authority has no power to compel the proprietor to surrender its freehold title. The State Authority should act reasonably and not arbitrarily even though it may impose any other requirement State Authority thinks fit.

Section 124(8) of the NLC provides that the new rent and premium under this section shall become due to the State Authority at the time when it approved the application for the conversion of land use and served on the proprietor a notice in Form $7 \mathrm{G}$ requiring him to pay such sum within the specified time and if any such sum is not paid within such time the approval of the State Authority shall thereupon lapse.

For the purpose of determining the premium, the Land Administrator will request the Valuation and Property Services Department of Malaysia (JPPH Malaysia) to carry out the valuation. It is noted that the premium of commercial lands is the most expensive, followed by limited commercial and then residential. Factors such as the leasehold expiry term would also determine the valuation process. The valuation is always done on the value of the land and not on the size of the building (Brenda Ch'ng, 2016). In Penang, although the State authority allowed for the conversion from residential to limited commercial, the residents claim their land was over-valued by the Valuation and Property Services Department. Hence, although 633 lot owners were entitled to the conversion, only 110 owners applied for and received planning approval from 2014-August 2016. However, of those who have planning approval, 59 applied for a change of land use, and only 40 of them received approval. Out of the 40, only 14 owners paid 
Nuraisyah Chua Abdullah, Azni Mohd Dian, Ramzyzan Ramly

Express Condition of Land, Usage of Property, And Licensing of Short-Term Accommodations

the premium (98\% yet to accept land conversion in Petaling Jaya). The difference in land valuation was up to RM1mil in some cases. The land premium was between RM300,000 and RM500,000 per lot to be settled within six months, after a discount given by the state government (Brenda Ch'ng, 2016).

In Selangor, the premium rate is as follows: agriculture to residential $(15 \%)$, agriculture to commercial $(30 \%)$, agriculture to industry $(20-30 \%)$, residential to commercial $(15 \%)$, and industry to commercial $(10 \%)$. The calculation of the additional premium is based on the State Land Rules. The basis and rates of premium differ between the respective states in Malaysia. Almost in all cases, a market value has to be determined. JPPH Malaysia will report the valuation to the Land Office/Land and Mines Office within ten working days upon receipt of the application. Where a valuation is required, the valuation would be the market value for the new use and the market value for the existing use. The percentage rate and the basis for the computation of additional premiums are provided in the respective State Land Rules.

Among the factors that are taken into consideration in the valuation are the condition of the land as at the date of valuation, the type of development that can be approved, location, shape, and size of the subject land. Information required from the proprietor is a copy of the title; address of the property (if any); site plan; location plan; development proposal; feasibility study (if any), and valuation report (if any).

\section{STRUCTURE AND LOCAL PLAN VS FOREIGN ZONING LAWS}

The Malaysian town planning system consists of two types of development plans: structure plans and local plans. While the former provides general policies of the state governments, the latter are statutory and detailed plans of the local authorities. The formulation of the development plans is fundamental and relevant to the growth of STAs in Malaysia. In the preparation process of both the structure and local plans, Section 7 of Act 172 requires the State Director to consider all matters expected to affect the development, such as the principal physical, economic, environmental, and social characteristics, including the primary land uses, of the State and, those of the neighboring areas. Section 8(3) of the Act 172 defines a structured plan for a state as a written statement formulating the policy and general proposals of the State Authority in respect of the development and use of land in that State, including measures for the improvement of the physical living environment, the improvement of the socioeconomic well-being and the promotion of economic growth and for facilitating sustainable development. The state structural plans serve as the framework for spatial planning at the local level in the form of a local plan. Section 12(3) of the Act 172 defines a local plan as a detailed land-use plan (map) supported by written statements explaining proposals for the development and use of land in the area. The local plans can be prepared by the local planning authorities or the 
state planning department at any time during the preparation of or upon the coming into effect of a structural plan.

Unfortunately, it is silent on specific matters concerning the permissibility and non-permissibility of STAs. Lack of concerns on this issue during the preparation of the structure and local plans will continue to lead to the vagueness as to the permissibility of the STA operation. It would appear that reference to the NLC about the express condition on the land and the Act 172 will continue to govern the STAs.

In foreign jurisdictions, for example, in the U.S.A, there are Zoning Ordinances which generally provide for sub-categories and statutory definitions. Residential districts are separated into single-family and multi-family. In Belle Terre, the city may go so far as to restrict a single-family dwelling use to only members of the same family unit with no more than two unrelated persons (Vill. of Belle Terre v. Boraas, 1974), whereas the Austin Ordinance limits the occupancy to six-unrelated-person rule (Austin, 2016). A foreign court had concluded that Zoning Ordinances must specify the non-permissible rule of STAs expressly to enable the local authorities to take action against illegal STAs, and in the absence of a definition of types of STAs in the Zoning Ordinances, there should be no restriction to the activities allowed in residential premises (Slice of Life, LLC v. Hamilton Twp. Zoning Hearing Board). On the contrary, there is no specific law on zoning except under Act 172. There is the development plan (Structure Plan and Local Plan) as mentioned earlier.

\section{GOVERNANCE OF LOCAL AUTHORITIES IN USAGE OF PREMISE FOR STAS}

Under Act 172, the local authorities have the right to allow or prohibit owners of properties from carrying out commercial business such as STA in their properties. Various local authorities use different approaches in addressing this issue, and this is influenced by the fact that every community's needs are different, changing, and the increasing demand of pursuit of quality life and influence of human rights (Meng Lee Lik et al., 2006). For example, the Penang Municipal Council stressed that landlords need to verify the allowed uses for their properties in Penang from the local Planning Department before they engage in a short-term rental.

On 16 October 2017, the Kota Kinabalu City Hall (DBKK) confirmed it was illegal for Sabah residents to lease their properties through Airbnb. Hence, the scrutiny behind the approval of operation of STA as a type of "property development" where planning permission needs to be obtained must be addressed.

Act 172 defines property development as "the carrying out of any building, engineering, mining, industrial or other similar operations in on, over or under land, or the making of any material change in the use of any buildings 
Nuraisyah Chua Abdullah, Azni Mohd Dian, Ramzyzan Ramly

Express Condition of Land, Usage of Property, And Licensing of Short-Term Accommodations

or other land, or the subdivision or amalgamation of lands" where planning permission needs to be obtained. In broad terms, development can be divided into two categories;

i. the carrying out of physical operations such as building or engineering works, and

ii. the making of a material change of use

A change of use of land or buildings requires planning permission if it constitutes a material change of use. There is no statutory definition of 'material change of use'; however, it is linked to the significance of a change and the resulting impact on the use of land and buildings (Mohammad Yusup et al., 2018). Whether a 'material change of use' has taken place is a matter of fact and degree, and this will be determined on the individual merits of a case. Planning permission will not normally be required to homework or run a business from home, provided that a dwelling house remains a private residence first and business second (or in planning terms, provided that a business does not result in a material change of use of a property so that it is no longer a single dwelling house). In the United Kingdom, a local planning authority is responsible for deciding whether planning permission is required and will determine this on the basis of individual facts. Issues which they may consider, whether home working or a business, leads to notable increases in traffic, disturbance to neighbors, abnormal noise or smells, or the need for any major structural changes or major renovations. This is in line with the idea that the happiness of residence is very much dependent on the neighborhood (Oliver Ling Hoon Leh et al., 2015). Hence, it may be concluded that normally planning permission is needed when (1) whether there has been a material change of use will depend on whether a space is used in a significantly different way as compared to the original position of the premise and (2) whether there are any other relevant planning considerations, such as planning conditions, which impose restrictions on the operation of the premise being opened for public accommodation (Ministry of Housing, 2014). It could also be argued that the "use" allowed is based around "A one-family dwelling on each building site." A home may be built as a one-family dwelling, but when it is converted to STA use, it may be argued that it loses that character and contributes to unauthorized changes in neighborhood character by intensifying the use both in terms of the number of people who typically use the property at any given time and by the negative impacts associated with frequent turnover. It would appear that some considerations are: if the premise is not used for a whole year period (i.e., limited operation days in a year) or where the owner stays in the same house, then planning permission is not needed. One possible way to address the "change of character' issue is by differentiating the types of short-term accommodation businesses.

In Austin, Texas, STRs can essentially be characterized by: (1) homesharing, (2) home rental, or (3) transient rental. Under the "Home sharing" model, 
PLANNING MALAYSIA

the guest and the host are co-occupants of the premises during the guest's stay. Home-sharing maximizes the accountability of the host because if the guest causes any nuisance to surround neighbors, the host is right there to deal with the problem.

Under the "Home rental" model, the host uses her primary residence for the STA, but instead of restricting the guest to one room or STA unit, the guest has rented the entire dwelling, and the host does not occupy the home during the guest's stay. A host under the home rental model is less accountable than under the home-sharing model.

Under the "Transient rental" model, the host is essentially operating an income property that does not serve as the host's primary residence but is for the sole purpose of STAs. Hosts utilizing the transient rental model are the least accountable of the three models. On the other hand, in the City of New Orleans, U.S. state of Louisiana, three different categorizations are provided. Under the category of Accessory Short-Term Rentals. The portion of the dwelling licensed as an Accessory Short-Term Rental is limited to three (3) bedrooms, and occupancy is limited to six (6) guests. (There must be at least one bedroom in the dwelling for the owner-occupant.) The owner-occupant shall occupy the dwelling and be present during any Short-Term Rental occupancy. Proof of owneroccupancy will be established by verification of a Homestead Exemption in the name of the applicant. However, Short-Term Accessory Rentals are prohibited in the French Quarter. Under the Temporary Short -Term Rentals category, an intown property manager is available at all times. Temporary Short-Term Rental licenses allow a maximum of 90-rental nights per license year. Occupancy is limited to two (2) guests per bedroom or a total of ten (10) guests, whichever is less. The entire dwelling may be rented, and the owner/occupant of the dwelling does not need to be present. No signs advertising the presence of a Short-Term Rental are allowed. Temporary Short-Term Rentals are prohibited in the French Quarter.

Under the Commercial Short-Term Rentals category, rental of an entire dwelling is allowed, where occupancy is limited to five (5) bedrooms and ten (10) guests. The owner/occupant does not need to be present during the rental period, and there is no limitation on the number of rental nights per license year. This type of business must be in a non-residential zoning district. Commercial ShortTerm Rentals are prohibited in non-VCE portions of the French Quarter. In the City of Charleston, South Carolina, Short-Term Rental regulations now have four Residential Short-Term Rental Permit Categories based on location. Category I refers to all properties located within the City's Old and Historic District. Within that area, the property must be individually listed on the National Register of Historic Places to be eligible for short-term renting. Category II refers to all other properties located on the Charleston peninsula, as long as they are outside the Short-Term Rental Overlay Zone. Category III refers to all other properties in the 
Nuraisyah Chua Abdullah, Azni Mohd Dian, Ramzyzan Ramly

Express Condition of Land, Usage of Property, And Licensing of Short-Term Accommodations

City of Charleston. This includes incorporated areas of West Ashley, James Island, Johns Island, Cainhoy, and Daniel Island. Under the past regulations, these areas are not eligible for any short-term legal rentals, but the ordinance allows short-term renting in these areas, subject to specific requirements. The STR Overlay Zone refers to a pre-existing area in Cannonborough-Elliotborough. Commercial Short-Term Rental Permit, which follows the same rules as the past ordinances. Properties within the Short-Term Rental Overlay are still eligible for a Bed \& Breakfast Permit as defined under past ordinances. No changes to this area have been made, except that an annual Permit renewal will be required.

Limiting the character of use in the property can be an option to maintain the character of the STA premise. In the City of Charleston, to ensure that the STA does not change the character of the property, a maximum guests rule is applied where up to four adults, regardless of relationship, can stay overnight in an STA according to the City of Charleston Short Term Rental Ordinance, 2018, whereas studio apartments and dwelling units shall be limited to have one (1) guest bedroom and allowed a maximum of two (2) guests in the City of New Orleans, the U.S. state of Louisiana under Article 20 of Comprehensive Zoning Ordinance, 2016 (20.3.LLL.1). In the City of Charleston also, a host must sleep overnight at the property whenever it is being rented. The Austin, Texas, Code of Ordinances 2015, § 25-2-795(E), reads: "A licensee or guest may not use or allow another to use a short-term rental for an outside assembly of more than six adults between 7:00 a.m. and 10:00 p.m." Furthermore, "assembly" was defined in the statute to encompass any activity "other than sleeping." Hence, if an STR guest wanted to host a barbeque at his rental, he would be capped at five friends or family members, no matter the scale of the rental. When read along with subsection(D) ("[a] . . guest may not use or allow another to use a short-term rental for an assembly between 10:00 p.m. and 7:00 a.m."), there is a strong term of "a bedtime for tenants."

\section{LICENSING OF STAS IN THE PURVIEW OF LOCAL AUTHORITIES}

Under the Local Government Act 1976, section 107, a local authority in the granting of any license or permit may prescribe the fees for such license or permit and the charges for the inspection or supervision of any trade, occupation, or premises in respect of which the license is granted. Under clause (1A), any license or permit granted under this Act may be issued jointly with any other license or permit. Under clause (2), every license or permit granted shall be subject to such conditions and restrictions as the local authority may think fit and shall be revocable by the local authority at any time without assigning any reason therefor. Under clause (2A), the revocation of any particular license or permit issued jointly with any other license or permit under subsection (1A) shall not affect the validity of any other license or permit with which it had been jointly issued. Under 
PLANNING MALAYSIA

Journal of the Malaysia Institute of Planners (2021)

clauses (3) and (4), respectively, the local authority may at its discretion refuse to grant or renew any license without assigning any reason; therefore and a license shall be valid for a period not exceeding three years.

Under clause (6), any person who fails to exhibit or to produce such license under subsection (5) shall be guilty of an offense and shall on conviction be liable to a fine not exceeding five hundred ringgit or to imprisonment for a term not exceeding six months or to both. In order words, violation of the licensing requirement of short-term accommodation by respective local authorities would lead to a maximum penalty of fine not exceeding RM 500, where quite unlikely the imprisonment provision is being imposed. Hence, the small amount of RM 500 would unlikely lead to deterrence, especially when the local authorities are not given the power to stop the business physically, for example, by way of eviction.

Under section 110, an officer of a local authority duly authorized in writing may at all reasonable times enter any premises (including that of STAs) within the local authority area for the purpose of exercising any power of inspection, inquiry, or execution of works which is given to a local authority. Under section 111, the Officer of the local government may demand names and addresses. Under clause (1), the occupier of any premises within the local authority area shall, if required by any officer of a local authority, give his name and identity card number and the name and address of the owner of the premises, if known. Under clause (2), any person who refuses to give or wilfully misstates his name and identity card number or the name and address of the owner of the premises shall be guilty of an offense and shall on conviction be liable to a fine not exceeding five hundred ringgit or to a term of imprisonment not exceeding six months or to both.

Currently, different states have different treatments on STAs, but Penang has set a good path to protect and preserve the property market and hotel industry. Penang prohibits illegal short-term accommodation to support and protect their tourism industry in line with the long-known promotion of medium-cost hotels in Malaysia (Badaruddin Mohamed \& Abdul Aziz Hussin, 2003) as well as to preserve the property market. Last July 2017, the Penang Island City Council issued summons to landlords after receiving complaints that they were leasing their premises for STAs purposes. The Environment Health and Licensing Department of Penang regarded short-term rental operators who operate without a legal license as operating an illegal lodging house.

Most local authorities have by-laws that govern guests' houses; for example, Hotel Act (Wilayah Persekutuan Kuala Lumpur) 2003 and Hotel Bylaws (Seberang Perai) 2017 require all accommodation providers who render accommodation as a guest house to be registered and to operate under a valid operating license. It is reported that landlords or property owners in the Penang Island City Council who ignore notices from the Penang Island City Council for 
Nuraisyah Chua Abdullah, Azni Mohd Dian, Ramzyzan Ramly

Express Condition of Land, Usage of Property, And Licensing of Short-Term Accommodations

them to cease their unlicensed short-term rental activity were issued the summons as the property owners violated the Trade, Businesses and Industries Bylaws of 1991 by the Municipal Council of Penang Island. Hotels Malacca (Historic City Council) By-Laws 2011, Hotels (Alor Gajah Municipal Council) By-Laws 2011, Hotels (Jasin Municipal Council) By-Laws 2011, and Hotels (Hang Tuah Jaya Municipal Council) By-Laws 2011 are examples of a by-law which had attempted to cover STAs through its application of hotel which includes STAs, where rooms or any premise (terrace house and homes) including kampung stay, homestays and town stays are included in the definition of the hotel under the Bylaws. The scale of accommodation of rooms in hotels (including STAs), fire and noise prevention are covered. Basic documents are required in the registration of the STAs by local authorities in Melaka, i.e., copy of identity card, prove of ownership/tenancy agreement, prove of business registration, visual advertisement (if available), and proof of exit signage in the premise and fire extinguisher. If there is a renovation, an approval letter from the local authority and Fire and Rescue Department Malaysia is required.

\section{CONCLUSION}

Although there is the absence of federal legislation which has been enacted in direct response to the rise of STAs, there are existing specific laws that relate to the restriction of activities in ones' properties under the federal land law (NLC) and the restriction on the use of the property by local authorities. Although STAs issue has been a complex one to resolve, the fact remains that the current NLC is still binding in the general governance of the STAs, and the enactment of some specific by-laws by local authorities are seen as proactive actions by local authorities to govern the operation of STAs in the locality.

\section{ACKNOWLEDGEMENT}

The authors would like to thank Institut Penilaian Negara (INSPEN) for sponsoring this conference under the National Real Estate Research Grant (NAPREC) and Research Management Centre (RMC), Universiti Teknologi MARA for managing the fund.

\section{REFERENCES}

Abdul Aziz , A., Zakaria , H., \& Hamzah, A. (2011). The planning process of development project in the Malaysian context: A crucial brief overview. International Journal of Applied Science and Technology, 1(2), 74-81.

Alden, J., \& Awang, A. (1985). Regional development planning in Malaysia. Regional Studies, 19(6), 495-508.

Apallonia C. Wilhelm. (2018). Sharing is Caring: Regulating Rather than Prohibiting Home Sharing in Wisconsin. 101 Marq. L. Rev. 821.

Austin, T. (2016). Code of Ordinances. 25-2-795(G). 
Badaruddin Mohamed, \& Abdul Aziz Hussin. (2003). Journal of the Malaysian Institute of Planners Vol. 1 (2003), 35-46.

Brenda Ch'ng. (20 September 2016). Show how valuation is done, say landowners. Retrieved from The Star: https:/www.thestar.com.my/metro/community/2016/09/20/show-how-valuationis-done-say-landowners-premium-amount-still-too-high-even-after-50-discount/

Cory Scanlon. (2017). Rezoning the Sharing Economy: Municipal Authority to Regulate Short-Term Rentals of Real Property. SMU Law Review, Vol 70, Issue 2.

Faizah Ahmad. (2001-2011). Malaysian Development Plan System: Issues and Problems, One Decade after its Reform. Journal of the Malaysian Institute of Planners, VOLUME XIV (2016), 107 - 126.

Faizul Abdullah, \& Fatimah Yusof. (2016). Overview of Governance Of Land And Landed Properties In Malaysia. Journal Of The Malaysian Institute Of Planners, $107-126$.

Izuandi Yin, \& Jamalunlaili Abdullah. (2020). The Development Control of Urban Centre in Kuala Lumpur. Journal of the Malaysian Institute of Planners Vol. 18, ISSUE $3,313-325$.

Meng Lee Lik, et al. (2006). How We Failed To Plan for Habitability. Journal o.f the Malaysian Institute of Planners, 1-21.

Ministry of Housing, C. \&. (20 March 2014). When is permission required? Retrieved from www.gov.uk: https://www.gov.uk/guidance/when-is-permissionrequired\#changesofuse

Mohammad Yusup et al. (2018). Temporary Planning Permission In Development Control System For Urban Development. Journal of the Malaysian Institute of Planners Vol. 16 ISSUE 3, 143 - 155.

Nicole Gurran, \& Peter Phibbs. (2017). When Tourists Move In: How Should Urban Planners Respond to Airbnb? Journal of the American Planning Association, 83:1, 80-92.

Oliver Ling Hoon Leh, et al. (2015). The Relationship of Human Happiness and Neighbourhood Planning: Case Study Puchong Indah Housing Estate, Selangor. Journal of the Malaysian Institute of Planners, 51 - 64.

Slice of Life, LLC v. Hamilton Twp. Zoning Hearing Board. (n.d.). 180 A.3d 687.

Toronto City Planning Division. (2017). Zoning By-law and Zoning By-law Amendments to Permit Short-term Rentals. Report for Action.

Vill. of Belle Terre v. Boraas. (1974). 416 U.S. 1, 9 .

Received: $12^{\text {th }}$ July 2021. Accepted: $2^{\text {rd }}$ Sept 2021 